\title{
Monitoring land use and soil salinity changes in coastal landscape: a case study from Senegal
}

\author{
Sophie Thiam (D) Grace B. Villamor • \\ Laurice C. Faye $\cdot$ Jean Henri Bienvenue Sène $\cdot$ \\ Badabate Diwediga $\cdot$ Nicholas Kyei-Baffour
}

Received: 15 July 2020 / Accepted: 15 February 2021 / Published online: 10 April 2021

(C) The Author(s) 2021

\begin{abstract}
Soil salinity is a major issue causing land degradation in coastal areas. In this study, we assessed the land use and soil salinity changes in Djilor district (Senegal) using remote sensing and field data. We performed land use land cover changes for the years 1984, 1994, 2007, and 2017. Electrical conductivity was measured from 300 soil samples collected at the study area; this, together with elevation, distance to river, Normalized Difference Vegetation Index (NDVI), Salinity Index (SI), and Soil-Adjusted Vegetation Index (SAVI), was used to build the salinity model using a multiple regression analysis. Supervised classification and intensity analysis were
\end{abstract}

S. Thiam $(\bowtie)$

Department of Civil Engineering, WASCAL Climate Change and Land Use, Kwame Nkrumah University of Science and Technology, Kumasi, Ghana

e-mail: thiam.s@edu.wascal.org; thiama87@gmail.com

\section{S. Thiam $\cdot$ L. C. Faye}

Institute of Environmental Sciences, Cheikh Anta Diop

University of Dakar, BP 5005 Dakar-Fann, Senegal

e-mail: fayelaurice@gmail.com

S. Thiam · G. B. Villamor

Department of Ecology and Natural Resource

Management, Centre for Development Research (ZEF),

University of Bonn, Walter-Flex St. 3, 53113 Bonn,

Germany

e-mail: Grace.Villamor@scionresearch.com

G. B. Villamor

Scion, New Zealand Forest Research Institute, Ltd, Titokorangi Drive, Private Bag 3020, Rotorua 3046,

New Zealand applied to determine the annual change area and the variation of gains and losses. The results showed that croplands recorded the highest gain (17\%) throughout the period 1984-2017, while forest recorded 3\%. The fastest annual area of change occurred during the period 1984-1994. The salinity model showed a high potential for mapping saline areas $\left(R^{2}=0.73\right.$ and RMSE $=0.68)$. Regarding salinity change, the slightly saline areas $(2<\mathrm{EC}<4 \mathrm{dS} / \mathrm{m})$ increased by $42 \%$ whereas highly saline $(\mathrm{EC}>8 \mathrm{dS} / \mathrm{m})$ and moderately saline $(4<\mathrm{EC}<8 \mathrm{dS} / \mathrm{m})$ areas decreased by $23 \%$ and $26 \%$, respectively, in 2017. Additionally, the increasing salt content is less dominant in vegetated areas

\author{
J. H. B. Sène \\ Institute National of Pedology, Hann Maristes, Dakar, \\ Senegal \\ e-mail: jeanhenribienvenue@gmail.com \\ B. Diwediga \\ Laboratory of Botany and Plant Ecology, University \\ of Lomé, Lomé, Togo \\ e-mail: diwedigaba@gmail.com \\ N. Kyei-Baffour \\ Department of Agricultural Engineering, Kwame \\ Nkrumah University of Science and Technology, Kumasi, \\ Ghana \\ e-mail: nkyeibaffour@hotmail.com
}


compared with non-vegetated areas. Nonetheless, the highly concentrated salty areas can be restored using salt-resistant plants (e.g., Eucalyptus sp., Tamarix sp.). This study gives more insights on land use planning and salinity management for improving farmers' resilience in coastal regions.

Keywords Soil salinity change - Land use intensity analysis $\cdot$ Remote sensing indices $\cdot$ Coastal areas · Senegal

\section{Introduction}

Salinity is among the major environmental factors causing land degradation. It is estimated that nearly 831 million hectares of land in the world are affected by salt (Daliakopoulos et al., 2016; Legros, 2009). Soil salinity is one of the common environmental problems that affect agricultural production and land resources mainly in semi-arid and arid areas (Metternicht \& Zinck, 2003). Most of the semi-arid and arid areas are located in the subSaharan Africa, where low rainfall and high temperature are major factors influencing soil salinity dynamics (Sakadevan \& Nguyen, 2010).

Similarly, in Senegal, soil salinity causes soil degradation which subsequently reduces crop yield and affects food security (Fall et al., 2014). In fact, out of the 3.8 million ha of the cultivated lands in the country, 1.7 million ha are affected by salt at the national level (FAO/CSE, 2003) resulting from seawater intrusion. Additionally, land use/land cover changes also a major contributing factor to soil degradation in Senegal. Also, changes in the vegetation cover and extent of the salt marshes have considerably contributed to expansion of salt-affected areas which will result in further environmental degradation (Masoud \& Koike, 2006). Furthermore, intensive use of natural resources in areas where local communities depend on land for agricultural purposes and excessive logging or deforestation are practices that increase environmental degradation in the country (Masoud \& Koike, 2006). Indeed, soil salinity becomes a land use/land cover (LULC) issue when it inhibits plant growth, causing death of nearby trees and therefore contributes to the changes and transitions among land use types (Allbed et al., 2017). Moreover, soil salinity is also influenced by the adverse effects of climate change (i.e., sea level rise), and thus making it difficult to monitor and mitigate. In view of this, the continuous and long-term monitoring of the land use change is considered as an essential step for understanding soil salinity change and its effects on other land use types.

Application of remote sensing in detecting and monitoring land use and soil salinity changes has been very useful over the years (Allbed \& Kumar, 2013). Since 1960, remote sensing has been progressively applied to monitor and delineate salt-affected areas using aerial photos (Saleh, 2017). Currently, a variety of remote-sensing data and sensors have been developed and used to delineate salt-affected areas. Among them are LANDSAT, SPOT, IKONOS, and TerraASTER with the resolution ranging from medium to high as well as hyperspectral sensors (Metternicht \& Zinck, 2003; Azabdaftari \& Sunar, 2016). In recent years, various salinity and vegetation indices such as normalized difference vegetation index (NDVI), normalized difference salinity index (NDSI), salinity index (SI), and soil-adjusted vegetation index (SAVI) have been used to delineate salt-affected areas (Zhang et al., 2011; Taghadosi \& Hasanlou, 2017; Yossif, 2017; Allbed et al., 2017). By integrating multi-temporal imagery with biophysical data, these remote-sensing indices and soil properties may provide an accurate estimation of soil salinity changes. In this study, Landsat imagery data were used for the assessment as recommended in many land use change studies (Wu et al., 2008; Narmada et al., 2015; Allbed et al., 2017; Emad \& Emad, 2017).

In Senegal, many land use change studies have been carried out using remote-sensing techniques (Sylla, 1994; Wiegand et al., 1996; Parton et al., 2004; Abdul Qados, 2011; Sambou et al., 2016; Faye et al., 2016; Sambou et al., 2016; Barry et al., 2017). The results of these researches showed major changes in land use patterns over the past years. For example, the loss of mangrove and forested areas, expansion of agricultural lands and salt marshes, shift of islands, and loss of traditional rice fields mainly due to inappropriate land management (i.e., illegal tree logging), frequency of flooding and drought, and soil degradation (i.e., salinity and erosion). Despite the changes in land use patterns, the relationship between changes in soil salinity and land use changes remains lacking. Apparently, the Saloum river region, particularly Djilor district, as a coastal area, has suffered from salinization as 
a result of seawater intrusion, insufficient rainfall, and increased temperature since the drought of 1970 (Sambou et al., 2016). The salt accumulation process, in this zone, has led to the formation of saline soils, which makes the soil unsuitable for agricultural production (Thiam et al., 2019). Hence, complementing land use change assessment with soil salinity analysis may provide important information to identify land management practices that helps to cope with the negative impacts of soil salinity increase. For that purpose, this paper aims at investigating the soil salinity dynamics together with land use changes between 1984 and 2017 in Djilor district. These specific objectives were set out to help achieve the aims: (1) assess the land use/land cover changes and (2) build a soil salinity predictor model for salinity change estimation and mapping using satellite images, biophysical, and soil data.

\section{Materials and methods}

Study area

The study was carried out in Djilor district in Fatick Region at the west-central part of Senegal. It is located between latitude $13^{\circ} 54$ and $14^{\circ} 04^{\prime} \mathrm{N}$ and longitude $16^{\circ} 12$ and $16^{\circ} 20^{\prime} \mathrm{W}$ (Fig. 1). Djilor covers a total area of $444 \mathrm{~km}^{2}$ and bounded to north west by the Saloum River. It is located about $40 \mathrm{~km}$ from the sea and situated within the Saloum Delta Biosphere Reserve, which combines the characteristics of costal, estuarine, and lacustrine landscapes (PLD, 2009). Salinization has been noticed in many parts of the area, mainly due to seawater intrusion from the Saloum River and evaporation that has a great impact on soil fertility and crop production (Faye et al., 2005); this endangers the livelihoods and food security of communities

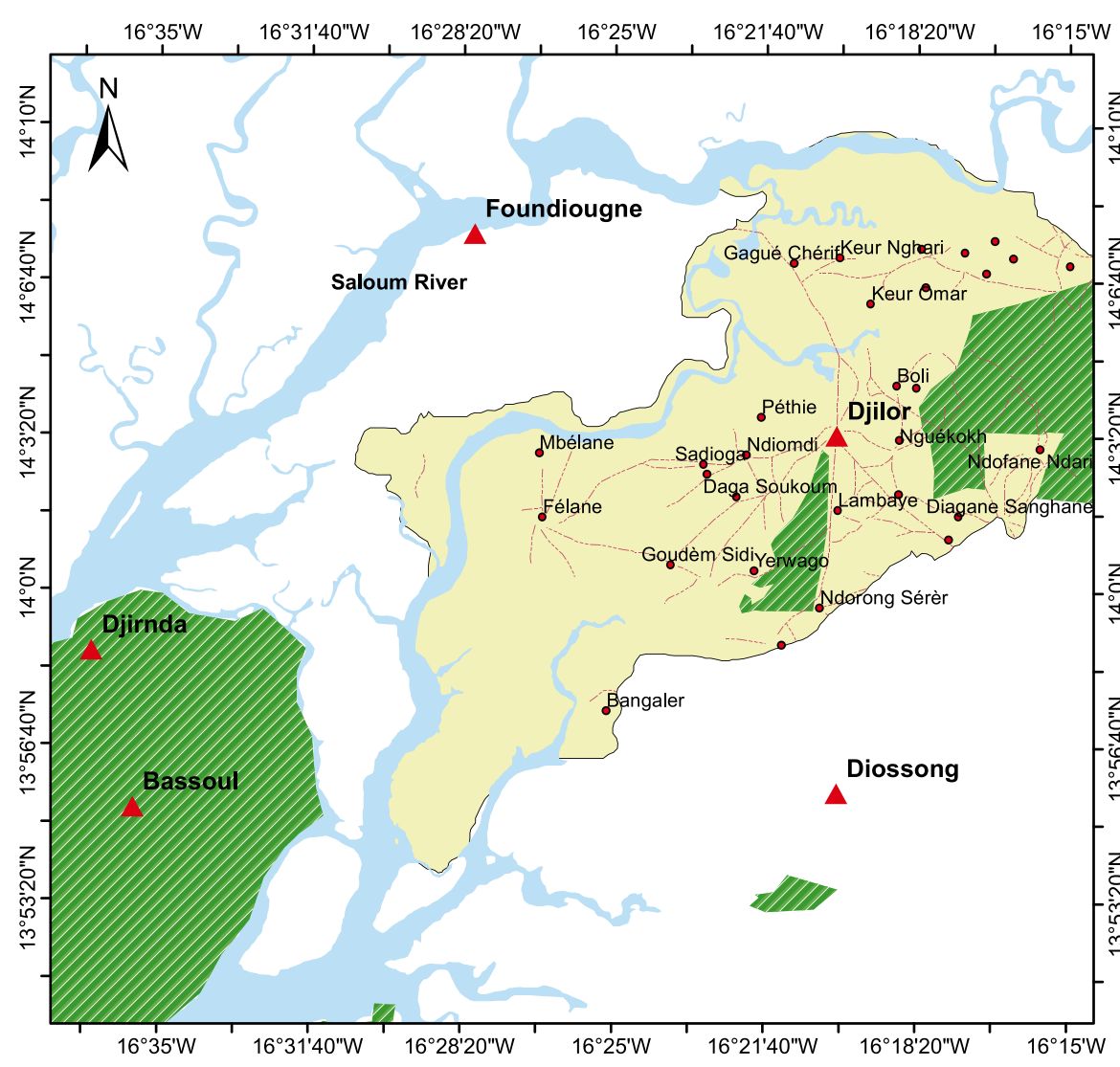

Projection: WGS 1984, Zone 28 N

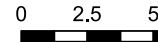

10 15

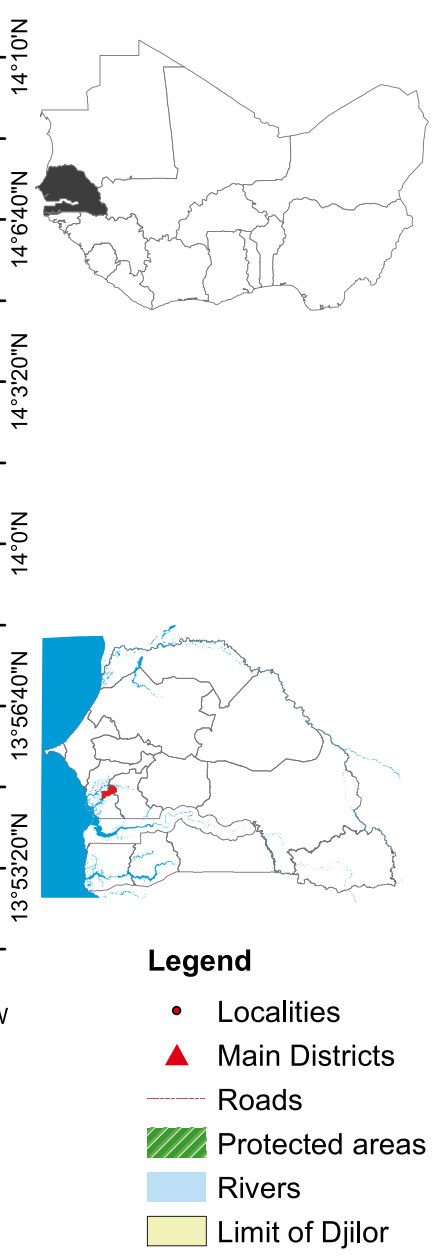

Springer

Fig. 1 Location of Djilor district, Fatick Region (data source: National Institute of Pedology) 
(Sambou, 2016). Groundnuts, millet, maize, sorghum, and rice are the main crops in Djilor. It is located in the Sudan-Sahelian zone, which is characterized by uni-modal rainy season from June to October and a dry season from November to May. Based on historical observations for the period of 1965 to 2016, the annual mean rainfall is estimated to be $546 \mathrm{~mm}$ (data source: Senegal National Meteorological Agency). However, the annual rainfall has fluctuated strongly with a major decrease during the period from 1970 to 1990 followed by a slight increase in annual rainfall from 2008 to 2016. In terms of the temperature, the region is characterized by an annual average temperature ranging from 28 to $31{ }^{\circ} \mathrm{C}$. The maximum temperature is noticed in April of about $39.55^{\circ} \mathrm{C}$. During cold periods (January to December), temperature can drop below $20.7^{\circ} \mathrm{C}$ (Senegal National Meteorological Agency, 2016).

Djilor is characterized by three dominant soil types: Lixisols (tropical ferruginous soils), Gleysols (hydromorphic soils), and Fluvisols (halomorphic soils). The tropical ferruginous soils, commonly known as "Dior" soils in Djilor, cover $52 \%$ of the total area, while hydromorphic soils, locally called "Deck soils", cover 9\%. The halomorphic soils known as acid sulfate soils also called "tann" in Djilor cover 29\% (PLD, 2009).

The coastal strands, tidal flats, depressions, and terrace uplands are the main geomorphological units of the area. The tidal channels and the topography mostly dominated by low land in the region; this has facilitated the degradation of the environment and the intrusion of saltwater into agricultural land (PLD, 2009).
Estimation of land use/land cover change

\section{Data source and pre-processing}

Four Landsat images for the years 1984, 1994, 2007, and 2017 were downloaded from United States Geological Survey and used to assess the patterns of land use/land cover (LULC). These images were acquired during the dry season between March and April to enable a clear distinction of features, especially salt surface features (Lhissou \& Chokmani, 2014). All the pre-processing including geometric and atmospheric corrections (Abd El-Kawy et al., 2011) and processing of the images were made using ERDAS IMAGINE 14. The images were all georeferenced to UTM WGS 1984 projection system. To train and validate the classified maps, a set of 164 points were collected by random sampling to represent the different LULC types using handheld GPS (Faye et al., 2016). A total of 114 points representing $70 \%$ were used for training purpose and the remaining 30\% for validation (Abdi, 2020). The field work was performed from April to May 2017 to collect information on historical LULC and validate the classified images using visual interpretation with Google earth historical images and local knowledge from key informants in the study area.

\section{Data processing and analysis}

A supervised classification was performed. The signature and the number of classes for the supervised classification were developed based on the field

Table 1 Description of the LULC types

\begin{tabular}{lll}
\hline Value & LULC & Description \\
\hline 1 & Mangrove & $\begin{array}{c}\text { Mangrove and estuaries with aquatic vegetation dominated by Rhizophora racemosa, Rhizophora man- } \\
\text { gle, and Avicennia Africana } \\
\text { Vegetation composed of tree savannahs, shrubs, and grasslands. Generally, tree height is lower than } 5 \mathrm{~m}\end{array}$ \\
3 & $\begin{array}{l}\text { Savannah/shrubs } \\
\text { Foodland or protected areas with trees height higher than } 5 \mathrm{~m}\end{array}$ \\
4 & Salt mashes & $\begin{array}{l}\text { Soil salt marshes, corresponding to the tidal areas and generally submerged } \\
\text { They are bordered by sabkhas and occur along the coast }\end{array}$ \\
5 & Sabkha & $\begin{array}{l}\text { Local term for tann, which soils are with salt crust on surface salt flat soils, characterized by very poor } \\
\text { vegetation cover composed mainly of halophytes }\end{array}$ \\
6 & Water bodies & $\begin{array}{l}\text { Rivers, reservoirs and lagoons } \\
\text { Abandoned areas, settlements }\end{array}$ \\
7 & Bare lands & Cereal crops and vegetables crops (e.g., rice, millet, maize, and groundnut) \\
\hline
\end{tabular}


investigation and the existing LULC classification map collected from the Centre of Environmental Monitoring (Centre de Suivi Ecologique). Eight main categories of land use/land cover types were identified and classified (Table 1). The accuracy assessment of the classification was checked by computing the confusion matrix, the overall accuracy, and the kappa coefficient for each year as well as the errors of omission and commission (Diwediga et al., 2017). To minimize classification errors due to image registration, all the classified maps were subjected to $3 \times 3$ pixels filtering to have a good homogeneity (Faye et al., 2016). The classified images were exported to ArcGIS for enhancement and mapping of LULC types of each year. Stepwise, a postclassification comparison was used for land use/land cover change (LUCC) detection.

Once the land use/land cover classification was established, the intensity analysis method was applied (Aldwaik \& Pontius, 2012). We particularly applied the interval and category levels to determine the time intervals during which the annual change area is relatively slow versus fast, and the variation of the categories' gains and losses during a time interval, respectively. Interval and category level analyses were performed using the following equations:

Equations 1 and 2 give the uniform intensity $(U)$ across time extent $\left(Y_{1}, Y_{\mathrm{T}}\right)$ and the annual change $\left(S_{\mathrm{t}}\right)$ for each time interval $\left(Y_{\mathrm{t}}, Y_{\mathrm{t}+1}\right)$, respectively. If $S_{\mathrm{t}}>U$, then the change is fast for $\left(Y_{\mathrm{t}}, Y_{\mathrm{t}+1}\right)$, if $S_{\mathrm{t}}<U$, then the change is fast for $\left(Y_{\mathrm{t}}, Y_{\mathrm{t}+1}\right)$, and if $S_{\mathrm{t}}=U$ for all time interval, then the annual change is stationary. As well, the category level was computed, this determines the variation of the categories' gains and losses during a time interval.

Equations 3 and 4 were used to calculate the change in terms of loss $\left(L_{\mathrm{ij}}\right)$ and gain $\left(G_{\mathrm{ij}}\right)$ for the four time intervals (Diwediga et al., 2017; Villamor et al., 2013).

$U=\frac{\text { (change area during all inteval) } 100}{\text { (duration of all interval)domain area }}$

$=\frac{\sum_{\mathrm{t}=1}^{\mathrm{T}-1}\left\{\sum_{\mathrm{j}=1}^{\mathrm{J}}\left[\left(\sum_{\mathrm{i}=1}^{\mathrm{J}} C_{\mathrm{t} \mathrm{jj}}\right)-C_{\mathrm{t} \mathrm{jj}}\right]\right\} 100}{\left(Y_{\mathrm{T}}-Y_{1}\right) \sum_{\mathrm{j}=1}^{\mathrm{J}} \sum_{\mathrm{i}=1}^{\mathrm{J}} C_{1 \mathrm{ij}}}$

$S_{\mathrm{t}}=\frac{\left(\text { change area during }\left[Y_{\mathrm{t}}, Y_{\mathrm{t}+1}\right]\right) 100}{\left(\text { duration of }\left[Y_{\mathrm{t}}, Y_{\mathrm{t}+1}\right]\right) \text { domain area }}$
$=\frac{\sum_{\mathrm{j}=1}^{\mathrm{J}}\left[\left(\sum_{\mathrm{i}=1}^{\mathrm{J}} C_{\mathrm{tij}}\right)-C_{\mathrm{tjj}}\right] 100}{\left(Y_{\mathrm{t}+1}-Y_{\mathrm{t}}\right) \sum_{\mathrm{j}=1}^{\mathrm{J}} \sum_{\mathrm{i}=1}^{\mathrm{J}} C_{\mathrm{tij}}}$

where $U=$ the uniform annual change during extent $\left[Y_{\mathrm{t}}, Y_{\mathrm{T}}\right] ; S_{\mathrm{t}}=$ the annual change during interval $\left[Y_{\mathrm{t}}\right.$, $\left.Y_{\mathrm{t}+1}\right] ; T=$ number of time points, which equals 4 for this study; $Y_{\mathrm{t}}=$ year at time point $t ; t=$ index for the initial time point of interval $\left[Y_{\mathrm{t}}, Y_{\mathrm{t}+1}\right]$, where $t$ ranges from 1 to $T-1 ; J=$ number of categories; $i=$ index for a category at an interval's initial time point; $j=$ index for a category at an interval's final time point; $C_{\text {tij }}=$ number of pixels that transition from category $i$ to category $j$ during interval $\left[Y_{\mathrm{t}}, Y_{\mathrm{t}+1}\right]$.

$L_{\mathrm{ij}}=\left(P_{\mathrm{i}}-P_{\mathrm{ii}}\right)\left(\frac{P_{\mathrm{j}}}{\sum_{\mathrm{j}=1} P_{\mathrm{j}}}\right)$, where $i \neq j$

$G_{\mathrm{ij}}=\left(P_{\mathrm{j}}-P_{\mathrm{jj}}\right)\left(\frac{P_{\mathrm{i}}}{\sum_{\mathrm{i}=1} P_{\mathrm{i}}}\right)$, where $i \neq j$

where $L_{\mathrm{ij}}$ is the proportion of loss from category $i$ to $j$ under random processes of loss and $P_{\mathrm{ii}}$ is the proportion of the category $i$ that showed persistence between the two times; $G_{\mathrm{ij}}$ is the proportion of gain from category $i$ to $j, P_{\mathrm{j}}$ is the proportion of the landscape in category $j$ in the final time; $P_{\mathrm{jj}}$ is the observed persistent proportion of the category $j ; P_{\mathrm{i}}$ is the total area of category $i$ at initial time.

\section{Estimation of soil salinity change}

In order to assess the spatial soil salinity change and predict the salinity level at different locations of the study area over the period 1984-2017, a total of 300 composite soil samples were randomly collected from the first top $30 \mathrm{~cm}(0-30 \mathrm{~cm}$ depth) in the different LULC types (Dahal \& Routray, 2011) (Fig. 2). These samples were brought to the laboratory to determine the electric conductivity (EC). The soil sample locations were georeferenced, and biophysical characteristics such as elevation, distance to river, wetness index (TWI) as well as remote sensing indices (NDVI), salinity index (SI), and soil-adjusted vegetation index (SAVI) were derived from Landsat image 2017 (Table 2).

These indices were chosen because they have given better correlation in the analysis of 
Fig. 2 Location of soil sample points

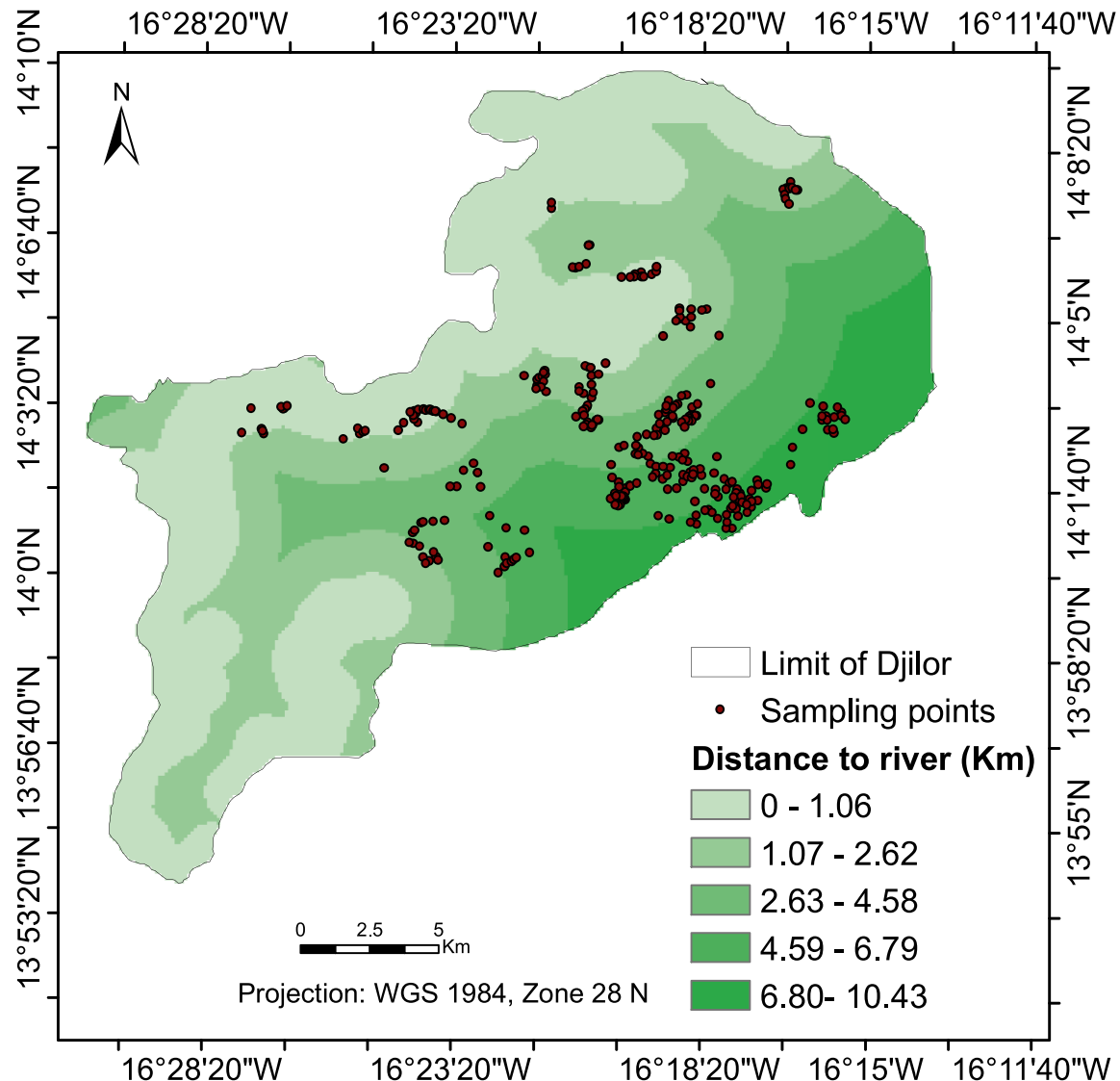

salt-affected areas and constitute good indicators for salinity classification and quantification (Poenaru et al., 2015). They were recently used in various regions to predict soil salinity distribution (Zhang et al., 2011; Taghadosi \& Hasanlou, 2017; Yossif, 2017; Allbed et al., 2017). Elevation and TWI were derived from DEM (i.e., $30 \mathrm{~m} \times 30 \mathrm{~m}$ resolution); DEM was obtained from the Directorate of Geographic and Cartographic Services in Senegal. Distance to the river was generated using Euclidian distance module in ArcGIS 10.3. The spatial analysis tool in ArcGIS was used to extract NDVI, SAVI, and SI values corresponding to each EC sampled point. A stepwise regression analysis was applied where remote sensing indices (SI, SAVI, and NDVI) and biophysical characteristics (elevation, distance to the river, and TWI) are independent variables whereas EC values are the dependent variable. At first, we included all these variables and conducted a stepwise regression in order to find the best fit model. The predicted EC generated from the regression model that showed the best correlation with EC was used to map soil salinity for the years 1984 and 2017. However, the regression salinity model was not applied to the 2007 image in order to reduce uncertainty in the change analysis (Yossif, 2017).
Table 2 Remote sensing indices

\begin{tabular}{lll}
\hline Index name & Formula & Source \\
\hline $\begin{array}{l}\text { Normalized differential vegeta- } \\
\text { tion index (NDVI) }\end{array}$ & $\frac{\text { Band 4-Band 3 }}{\text { Band 3+Band 4 }}$ & Tripathi et al. (1997) \\
$\begin{array}{l}\text { Soil-adjusted vegetation index } \\
(\text { SAVI) }\end{array}$ & $\frac{\text { Band 4-Band 3 }}{\text { (Band 3+Band 4+L) }}(1+L)$ & Wilson et al. (2016) \\
Salinity index (SI) & $\sqrt{\text { Band 3 } \times \text { Band 4 }}$ & Dehni and Lounis (2012) \\
\hline
\end{tabular}


The classification of salinity level is based on the global standard salinity ranges (Azabdaftari \& Sunar, 2016). From that, four salinity classes were considered in mapping salinity level (Table 3 ).

\section{Results}

Land use/cover change over the period 1984-2017

Figure 3 represents the land use/land cover maps of 1984, 1994, 2007, and 2017 of Djilor whereas their respective land use/land cover changes are shown in Table 4. Croplands and forests constitute the major land cover types with $20 \%$ and $18 \%$ of the total area in 1984, respectively. In 2017, cropland experienced the largest gain of $30 \%$ of the total area (Table 4 ).

The reliability of these different statistics has been confirmed by the accuracy assessment using kappa and the overall accuracy. The classification shows an overall accuracy of $86.58 \%, 88.13 \%, 97.22 \%$, and $99.68 \%$, respectively, for the years 1984, 1994, 2007, and 2017 (see Appendix 1). The results of kappa coefficients range between 0.86 and 0.99 , and overall accuracy is much enough and satisfactory to confirm the accuracy classified maps. However, the mangroves, salt marshes, and Sabkha were the most accurate classified land use types over time, while forest and savannah registered some classification errors mostly due to the confusion between them.

In terms of interval level, Fig. 4 shows that the annual area of change between 1984 and 1994 is faster than the annual area of change between 1994-2007 and 2007-2017. This can be attributed to forest loss and the gains of croplands and bare lands.

Figure 5 presents the gains, losses, and persistence of the major land use types for three-time intervals. During the first-time interval (1984-1994), bare lands registered the highest gain $(16.7 \%)$ followed by

Table 3 Categorization standard of soil salinity (Azabdaftari \& Sunar, 2016)

\begin{tabular}{ll}
\hline Salinity level $(\mathrm{dS} / \mathrm{m})$ & Salinity class \\
\hline$>8$ & Highly saline \\
$4-8$ & Moderately saline \\
$2-4$ & Slightly saline \\
$<2$ & Non-saline \\
\hline
\end{tabular}

croplands (8.8\%). In contrast, forests and croplands had more losses compared with gains. During the second time interval (1994-2007), croplands and bare lands had both the highest gains and losses suggesting that these land use types were highly dynamic. Within this time interval, forests decreased its cover by $6.4 \%$ as compared with the first-time interval (9.2\%). During the last time interval (2007-2017), croplands experienced the largest gain (14.5\%), followed by savannah (6.6\%). Contrarily, bare lands (15.8\%) had the highest loss followed by croplands $(9.7 \%)$.

Soil salinity predictor model

The selected regression model (Eq. 5) combining biophysical data and NDVI gives a greater correlation with EC $\left(R^{2}=0.73\right)$ compared with SI $\left(R^{2}=0.57\right)$ and SAVI $\left(R^{2}=0.55\right)$ (see Appendix 2). The distance to the river, elevation, and NDVI was significantly associated with EC $(P<0.05)$. The statistical significance of the regression is at the 0.05 level. The regression analysis has significant estimation (Prob $>F=0.000$ ) and good fit in the area with $R^{2}=0.73$ and $\mathrm{RMSE}=0$. 68 . The test for validation of the regression model showed a strong correlation between measured EC and predicted EC values, with the coefficient of correlation $\left(r^{2}=0.65\right)$ (Fig. 6). Hence, the regression model (Eq. 5) can be used to predict and map the saltaffected areas in the study area.

$$
\begin{aligned}
\mathrm{EC}=9.98 & -0.0005 \times d-0.20 \times \text { elevation } \\
- & 6.58 \times \mathrm{NDVI}+0.00007 \times \mathrm{TWI}
\end{aligned}
$$

Soil salinity change over the period 1987-2017

Figure 7 compares the soil salinity maps for the years 1984 and 2017 with four salinity classes (non-saline, slightly saline, moderately saline, and highly saline). Figure 8 shows the statistics of soil salinity level noticed in the area from 1984 to 2017. In 1984, moderate saline soils registered the higher coverage $\left(165.8 \mathrm{~km}^{2}\right)$, corresponding to $38.9 \%$ of the area. Highly saline areas cover $32.65 \%$ of the total area whereas slightly saline and nonsaline soils were lower in coverage representing 18.5 and $9.93 \%$, respectively. In 2017, the slightly saline areas are the highly represented in the area with $39.69 \%$, followed by moderately saline (25.6\%). Highly saline and nonsaline soils registered, respectively, 20.85 and $13.88 \%$. 

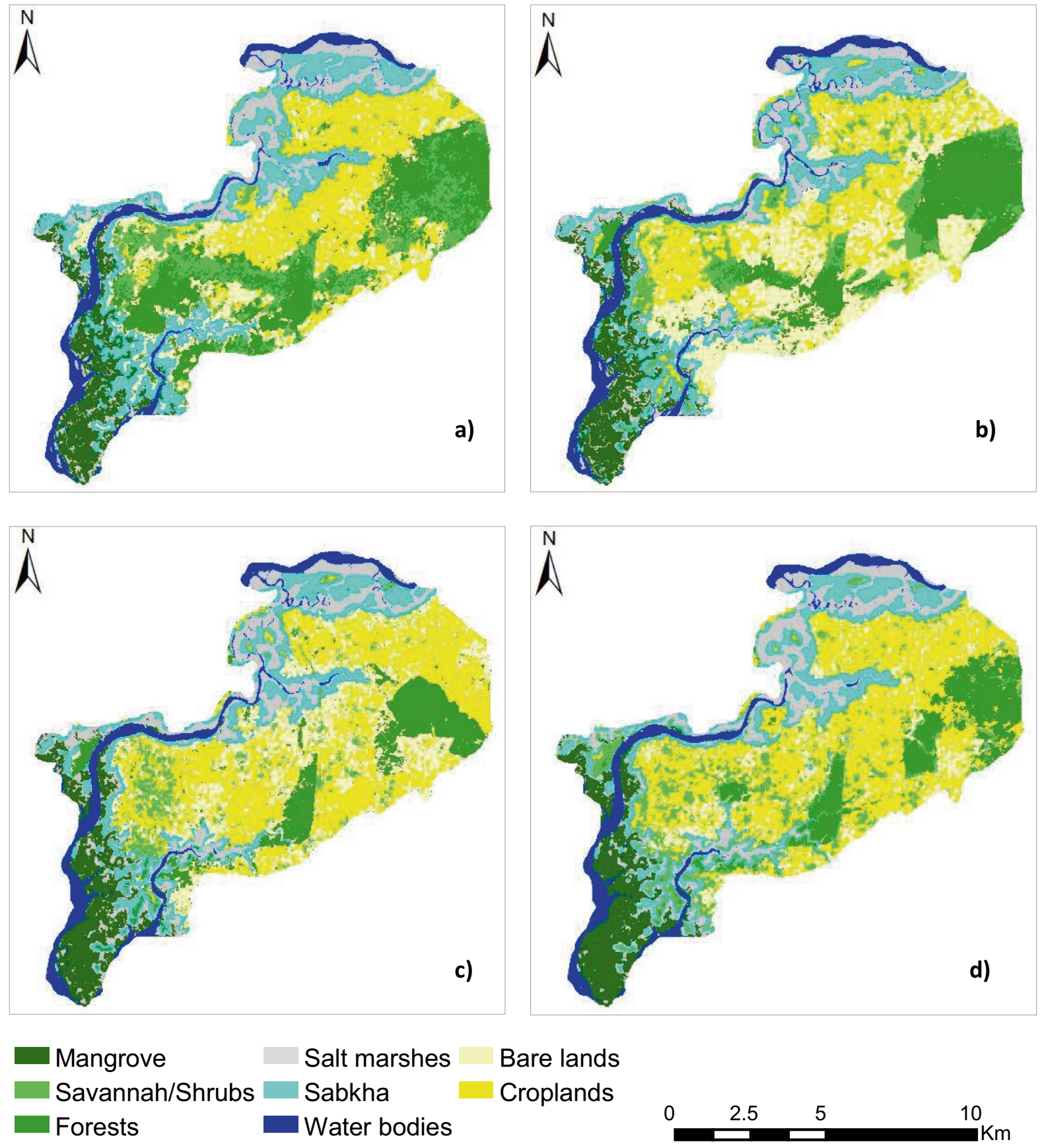

Fig. 3 Historical land use/land cover types in Djilor for the year 1984 (a), 1994 (b), 2007 (c), and 2017 (d)

The period 1984-2017 is characterized by a decrease in salinity level over the area. In fact, slightly saline and non-saline soils gained 42.14 and $7.85 \%$, respectively, between 1984 and 2017, while highly saline and moderately saline areas decreased in their area $(-23.47 \%$ and $-26.53 \%)$, respectively.

Figure 9 shows the percentage of salt effected areas per land use types for the years 1984 and 
Table 4 Land use/land cover statistic from 1984 to 2017

Areas in ha are rounded to avoid decimal figures

\begin{tabular}{|c|c|c|c|c|c|c|c|c|}
\hline \multirow[t]{2}{*}{ LULC } & \multicolumn{2}{|l|}{1984} & \multicolumn{2}{|l|}{1994} & \multicolumn{2}{|l|}{2007} & \multicolumn{2}{|l|}{2017} \\
\hline & ha & $\%$ & ha & $\%$ & ha & $\%$ & ha & $\%$ \\
\hline Mangrove & 2920 & 6.87 & 3158 & 7.43 & 3337 & 7.86 & 3876 & 9.13 \\
\hline Savannah/shrubs & 3908 & 9.20 & 3063 & 7.21 & 1836 & 4.32 & 3539 & 8.33 \\
\hline Forests & 7755 & 18.26 & 5895 & 13.88 & 4109 & 9.67 & 3881 & 9.14 \\
\hline Salt marshes & 4905 & 11.55 & 4829 & 11.37 & 5532 & 13.02 & 5550 & 13.07 \\
\hline Sabkha & 6008 & 14.14 & 4959 & 11.68 & 4492 & 10.58 & 5128 & 12.07 \\
\hline Water bodies & 2591 & 6.10 & 2868 & 6.75 & 2941 & 6.92 & 2740 & 6.45 \\
\hline Bare lands & 5886 & 13.86 & 9902 & 23.31 & 9268 & 21.82 & 5050 & 11.89 \\
\hline Croplands & 8502 & 20.02 & 7801 & 18.37 & 10,959 & 25.80 & 12,711 & 29.93 \\
\hline Total & 42,475 & 100 & 42,475 & 100 & 42,474 & 100 & 42,475 & 100 \\
\hline
\end{tabular}

2017. In general, non-vegetated areas (e.g., sabkha, salt marshes, bare lands, and croplands) have a higher coverage of salt-affected areas compared with vegetated areas (e.g., forest, savannah, and mangrove). In 1984, $31.04 \%$ and $27.88 \%$ of highly saline category areas were contained in sabkha and salt marshes, respectively. Croplands registered $19.13 \%$ of the moderately saline category soils, while savannah and forest had the lowest saline areas. In 2017, salt marshes and sabkha registered, respectively, $44.42 \%$ and $25.76 \%$ of highly saline category, while non-saline areas were more dominant in croplands $(45.30 \%)$ and forests $(24.11 \%)$.

\section{Discussion}

\section{LULC mapping and accuracy}

The land use land cover change analysis showed an increase in agricultural (17\%) and bare lands (9\%) at the expense of forest which was characterized by high loss (12\%) over the period 1984-2017. These results reveal the ongoing loss of vegetation in the area as shown by the decreasing trend of forest. Similar results were observed in the neighboring area of Fatick in Senegal (Sambou et al., 2016) and in SouthEastern part of Senegal (Faye et al., 2016). These changes in LULC are mainly due to human activities
Fig. 4 Interval level change intensity as an annual percent of the study

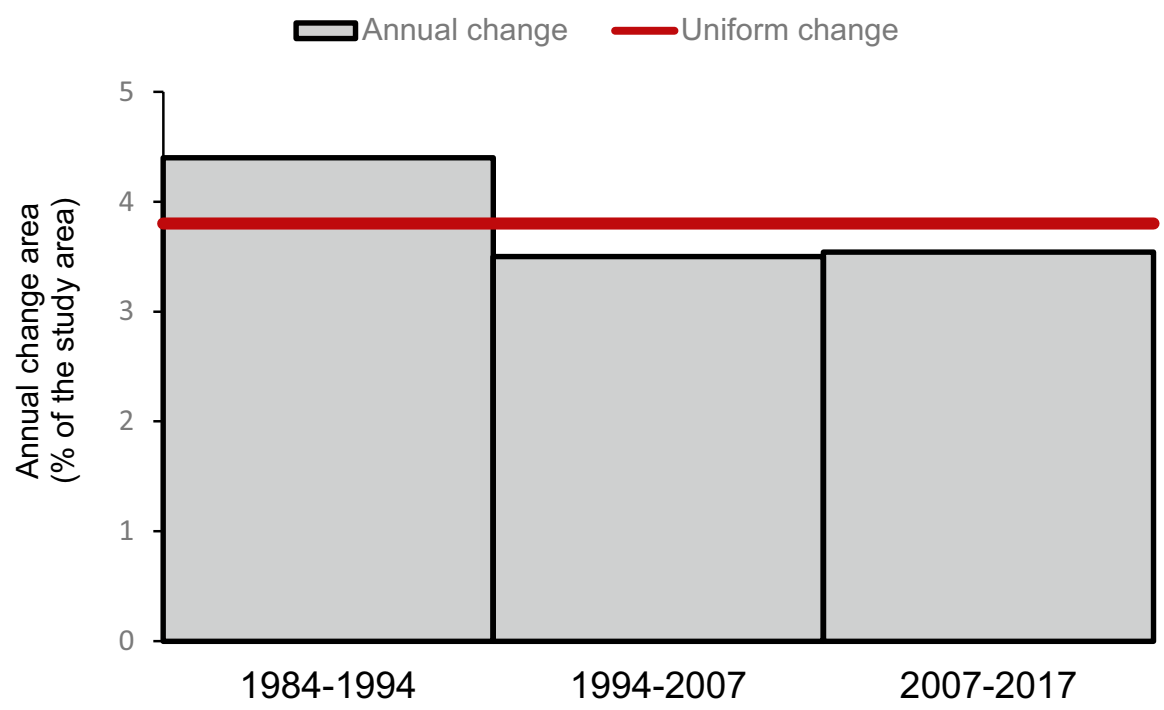


Fig. 5 Land use change persistence, gains, and losses for four-time periods
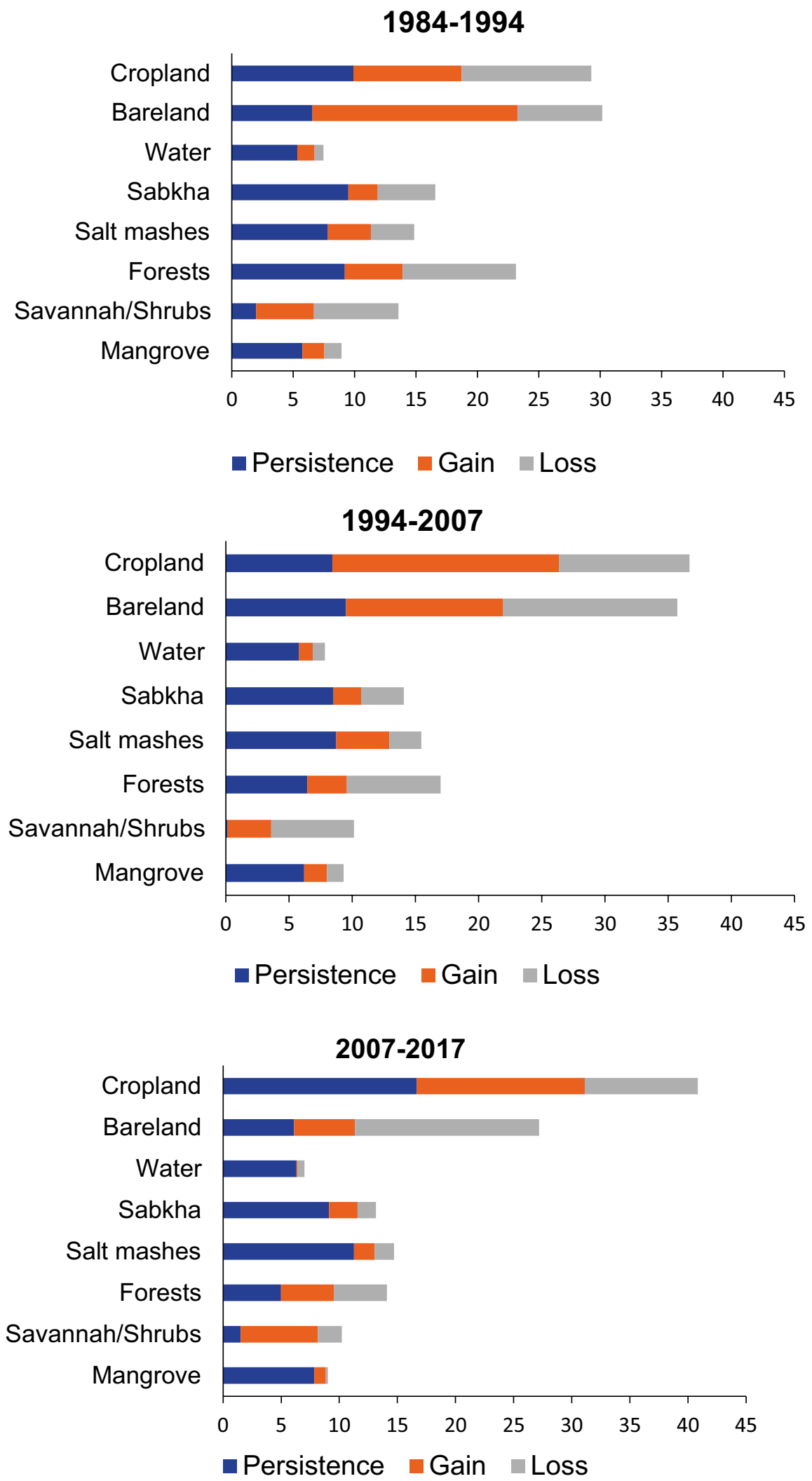
Fig. 6 Correlation between measured EC and predicted EC values

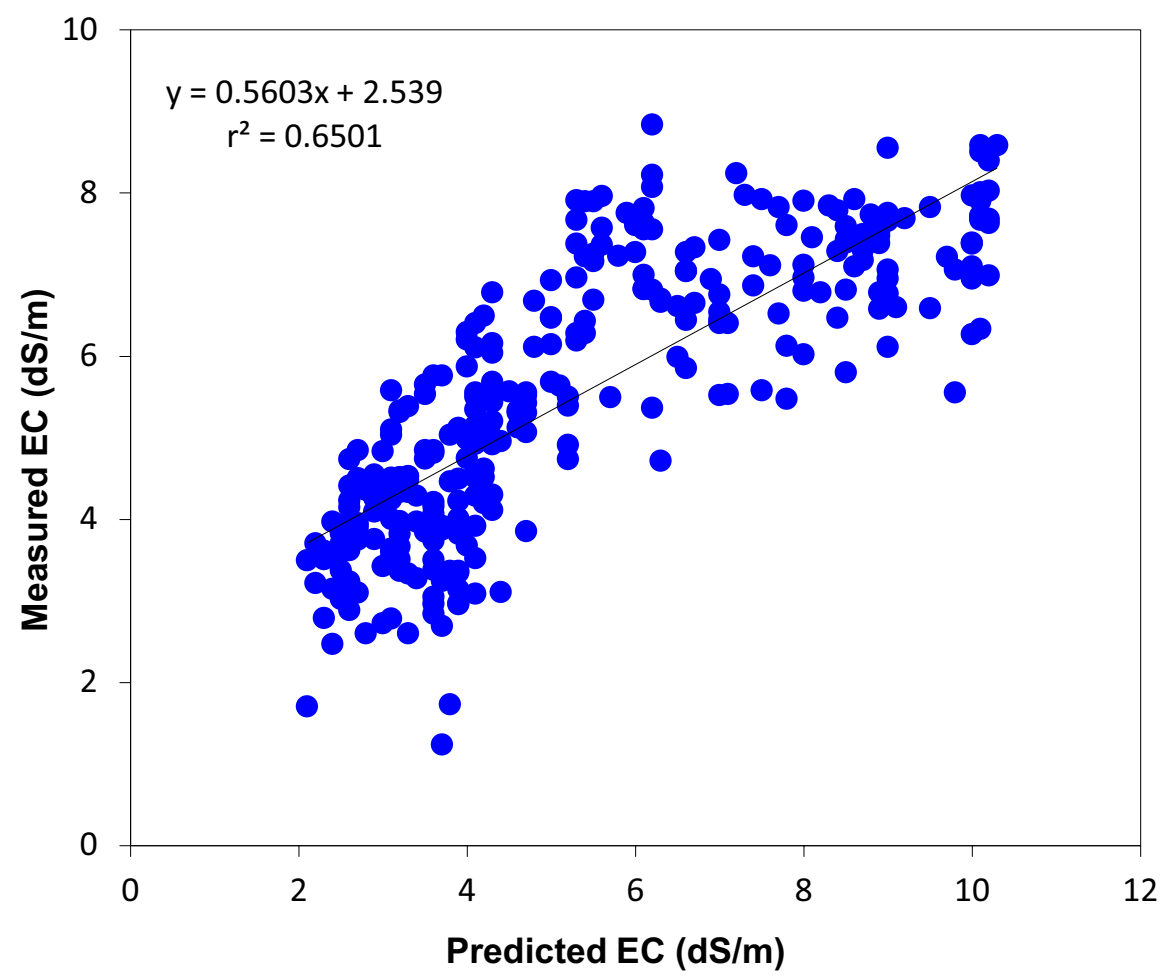

such as continuous expansion of farms to sustain food production. Also, salinization is a severe phenomenon that has contributed to LUCC and has caused the toxic effects on plant growth (Allbed et al., 2017). This could be seen in the percentage of salt-affected areas per land use/land cover type over the period 1984-2017. Indeed, the sabkha and salt marsh areas registered the largest highly saline coverage with, respectively, $31.04 \%$ and $27.88 \%$ in 1984 compared with forests (1.50\%) and croplands (8.92\%). Another important finding of this study was the reduction of highly saline areas by $5.28 \%$ and $7.17 \%$, respectively, in sabkha and croplands in 2017. This decrease can be explained by the slight improvement of rainfall in the area since the drought period of 1971, which contributed to leach out the salt from the soils. As well, LULC change was more intense $(4.40 \%)$ in the first period 1984-1994 (see Fig. 4). Historical evidence may explain this finding, since that period was characterized by an increasing resource pressures and land degradation due to severe events such as drought (Sadio \& van Mensvoort, 1993; Faye et al., 2020).
Soil salinity dynamics

Soil salinity was accurately mapped using multiple regression (Eq. 5) as earlier reported by Morshed et al. (2016). The results show that salinity level has been characterized by a relative decrease between 1984 and 2017 in the region. Indeed, highly saline and moderately saline areas have decreased by $23.47 \%$ and $26.53 \%$, respectively. These results confirm the reduction of the extent of salt-affected areas registered in the different land use type in 2017. Such decrease of salinity could be related to the improvement of rainfall recorded in the area (Descroix et al., 2020) as well as the various adaptation and mitigation measures (e.g., antisalt dams, revegetation and conservation of trees, use of manure and mulching, etc.) implemented by the local communities and some NGOs. Similarly, Sambou et al. (2015) showed slight restoration of affected areas by the construction of anti-salt microdam and the improvement in rainfall in Casamance (Southern Senegal). In addition, it was also noticed 


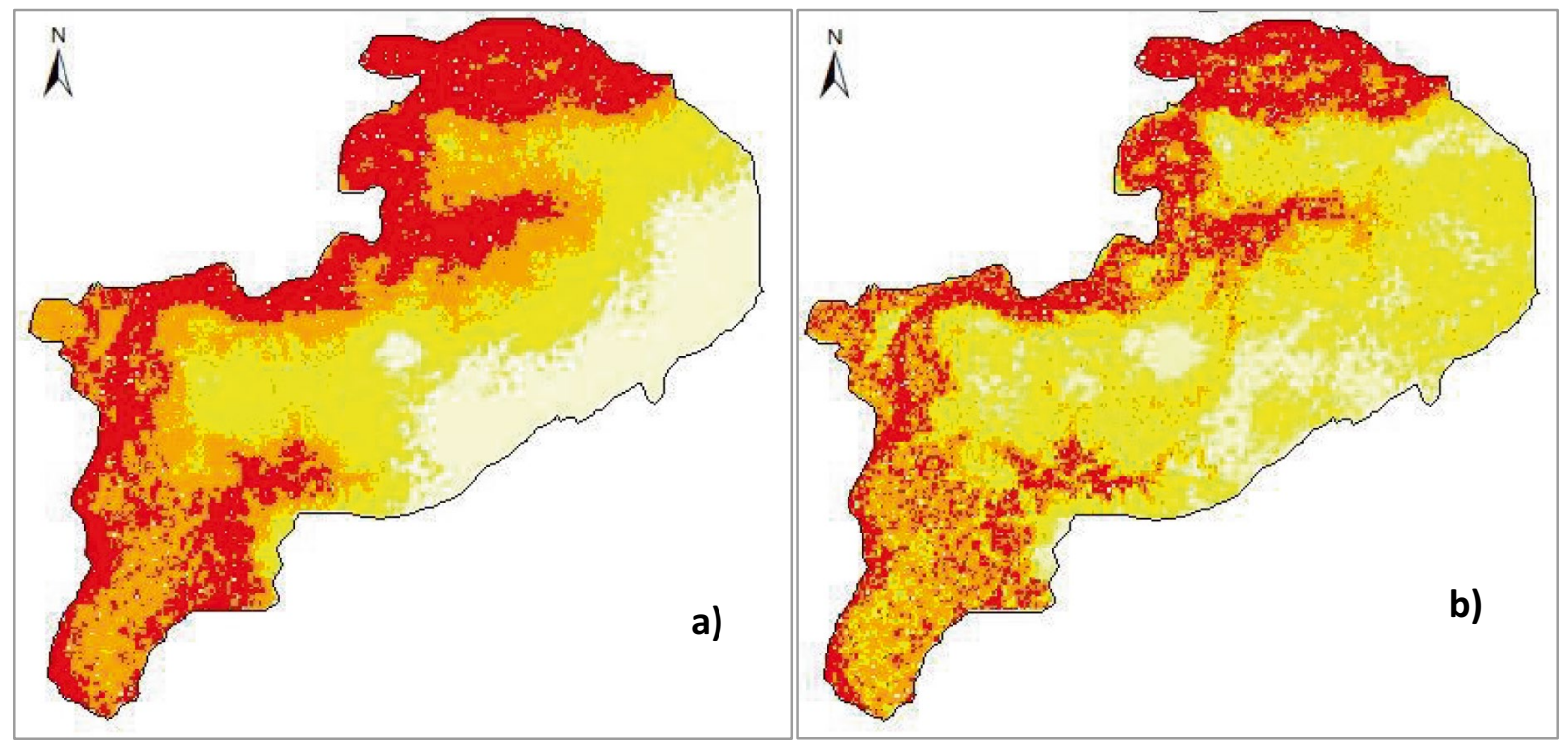

\section{Legend}

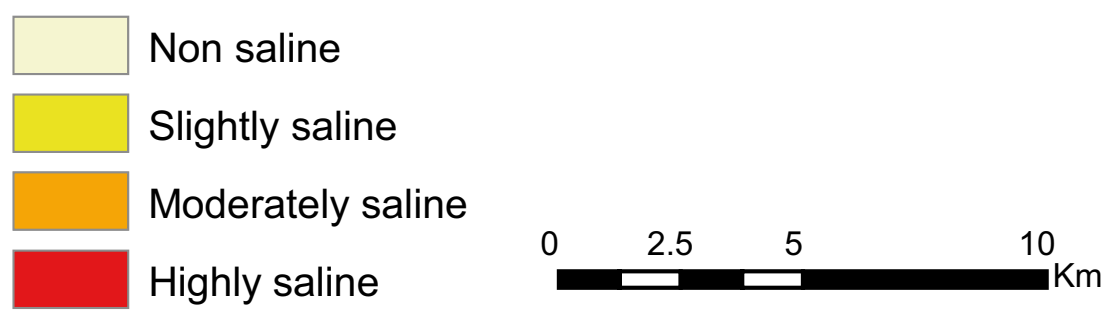

Fig. 7 Soil salinity maps for the years 1984 (a) and 2017 (b)

that year 1984 registered the higher salt-affected areas that may be explained by the deficit in rainfall during that year. In fact, from 1971 to 1985 , the Sahel in general, particularly Senegal, has been through a severe drought period characterized by a drastic reduction in rainfall which have contributed to the expansion of salt-affected areas in the country (Sadio \& van Mensvoort, 1993). Our finding is in accordance with the observation of Kairis et al. (2013) which reported that areas with low amounts

Fig. 8 Soil salinity change for the years 1984 and 2017

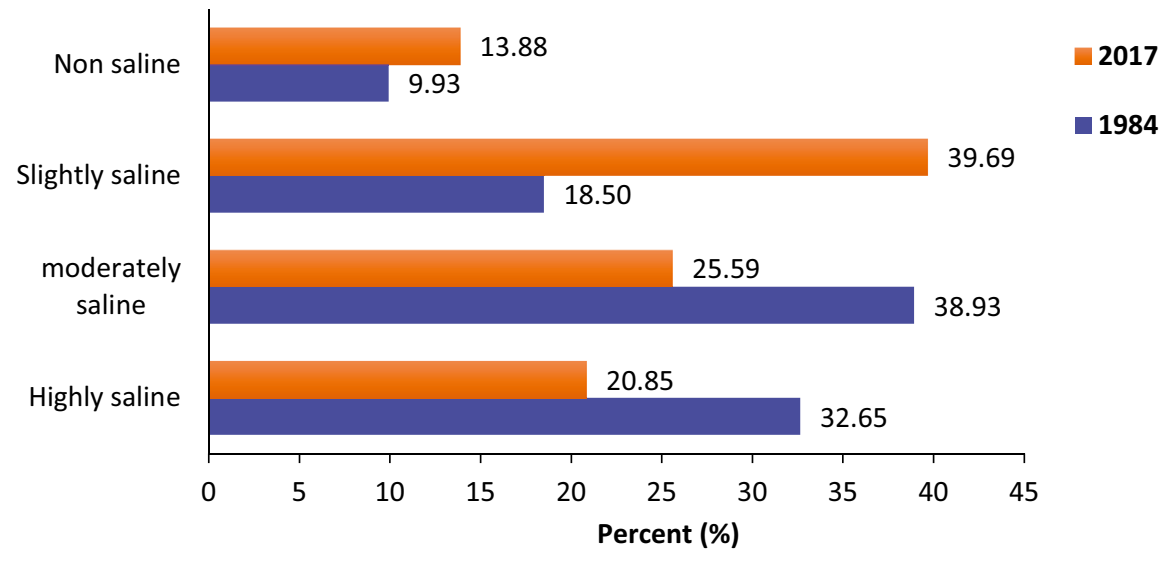


Fig. 9 Percentage of saltaffected areas per land use/ land cover type for the years 1984 (a) and 2017 (b)
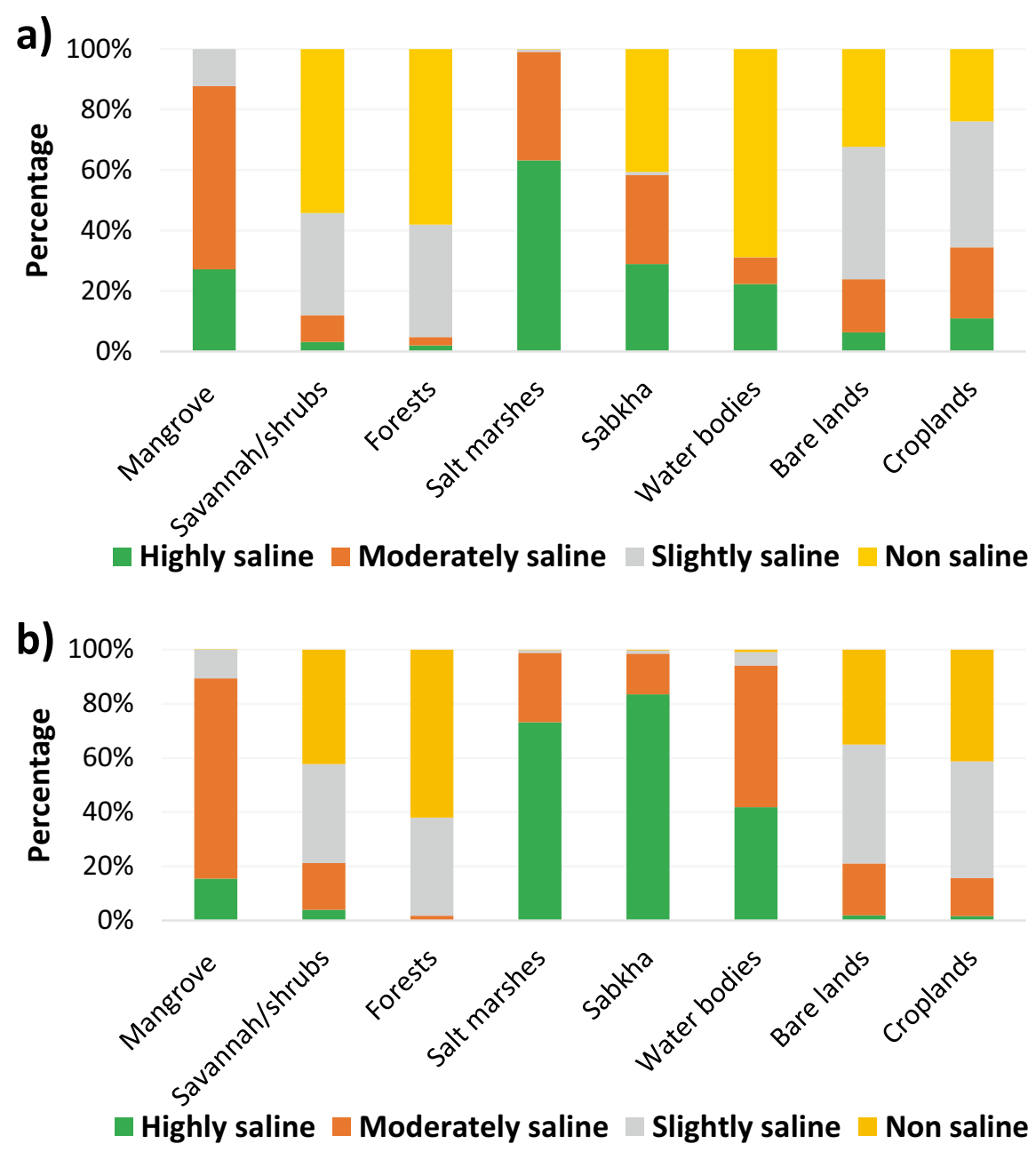

of rainfall (>650 mm) are more likely to be affected by salinity. This indicates that the decrease in rainfall resulting from climate change could accelerate salinization, but this requires further investigation in the study area. This indicates that, as a result of climate change, salinization may be hindered due to decreased rainfall and further research is required.

Additionally, the spatial distribution of salinity in Djilor showed that the highly saline areas are mostly located along the river, generally corresponding to the salt marshes and sabkha areas. Suggesting that the salinity gradient is mostly horizontal and gradually moving from the river to the uplands (Manandhar \& Odeh, 2014). These findings support the fact that soil accumulation in this region is generally caused by inundation and deposits of salt from seawater intrusion combined with a high temperature. Also, our results show that vegetation cover is a determining factor of spatial distribution of salinity in the area (Ivushkin et al., 2019). In fact, patches of non-saline soils are more pronounced in vegetated areas (Forests and Savannah), compared with non-vegetated areas (bare land and sabkha) which registered high content of salt. This finding corroborates with a study in Saudi Arabia (Oasis), which reported that vegetated areas exhibited the lower salinity, while high salinity was exhibited in non-vegetated areas (Allbed et al., 2017, 2014). This may suggest that planting salt-tolerant tree species may further reduce salinity but further need investigation.

Among the remote-sensing indices, NDVI appears relevant in the assessment of salinization because it gave a higher correlation $\left(R^{2}=0.73\right)$ compared with 
SI $\left(R^{2}=0.57\right)$ and SAVI $\left(R^{2}=0.55\right)$. These results are similar to those of Emad and Emad (2017) in northern Egypt and Jabbar and Zhou (2012) in Southern Iraq, who reported that NDVI index gives good results with assessing soil salinity. However, we have noticed during the stepwise regression that NDVI, coupled with biophysical data such as elevation, and distance to the river give high $r$-squared $\left(R^{2}\right)$. This result confirms the strong influence of biophysical factors in the expansion of saltaffected areas in Djilor and their importance in monitoring soil salinity in coastal regions (Thiam et al., 2019).

\section{Conclusion}

In this paper, we investigated the spatial patterns and dynamics of LULC, in salt-affected areas, over the period 1984-2017. Our results show that the dynamics of LULC in Djilor is characterized by an increase in croplands (17\%) at the expense of forest cover (12\% of loss).

These changes attest the ongoing deforestation in the area and the continuous expansion of farms by local communities who promote to soil degradation by expanding agricultural lands to sustain food production. Annual area of land cover change is faster during period 1984-1994 (4.40\%) than during 1994-2007 (3.50\%) and 2007-2017 (3.52\%). Historical evidence explains this finding, since there were increasing resource pressures and land degradation in 1984-1994 due to severe events such as drought.

Furthermore, changes in soil salinity level for the years 1984 and 2017 revealed a slight decrease. The highly saline areas decreased by $23.47 \%$ while slightly saline and non-saline areas gained $42.14 \%$ and $7.85 \%$, respectively. However, despite this decrease, soil salinity remains one of the main factor of soil degradation in the study area as salt-affected areas (i.e., highly saline and moderately saline areas) cover around $60 \%$ and $45 \%$ of the total area of Djilor in 1984 and 2017, respectively. Spatial distribution of soil salinity is mostly related to vegetation in the area. In fact, the highly saline soils were mostly located in the non-vegetated areas (Sabkha, Salt marshes, Croplands) while non-saline areas are situated in the vegetated areas (Forests and Savannah).

This paper gives a clear understanding of land use/land cover and soil salinity dynamics in Djilor, resulting from land management. Indeed, the results show a high potential of integrating remote sensing and field data to assess soil salinity. The findings are useful for guiding decision makers, land planners, and smallholder farmers to reverse vegetation decline and restore salt-affected areas through the adoption of land management practices as well as integrating new strategies for improving people's livelihood. Since vegetation is playing an important role in salinity distribution, more efforts should be done on regeneration of salt resistant tree species (e.g., Eucalyptus sp., Acacia sp., Tamarix sp.). With regards to the future effects of climate change (increased in temperature and sea level rise and decrease in rainfall), further investigations on modeling future soil salinity as well as assessing the impacts of some adaptation strategies on soil salinity may be useful for sustainable soil salinity management in the study area.

\section{Appendix 1 Accuracy assessment of the classified LULC maps (1984, 1994, 2007, and 2017)}

\begin{tabular}{|c|c|c|c|c|c|c|c|c|c|c|c|c|}
\hline \multirow{2}{*}{$\begin{array}{l}\text { Land use/cover } \\
\text { types }\end{array}$} & \multicolumn{8}{|c|}{ Ground truth (pixels) } & \multicolumn{4}{|c|}{ Accuracy assessment } \\
\hline & Mangroves & Savannah & Forests & $\begin{array}{l}\text { Salt } \\
\text { marshes }\end{array}$ & Sabkha & $\begin{array}{l}\text { Water } \\
\text { bodies }\end{array}$ & $\begin{array}{l}\text { Bare } \\
\text { lands }\end{array}$ & Croplands & $\begin{array}{l}\text { Prod } \\
\text { Acc. } \\
(\%)\end{array}$ & $\begin{array}{l}\text { Users } \\
\text { Acc. } \\
(\%)\end{array}$ & $\begin{array}{l}\mathrm{Ov} \\
\text { Acc } \\
(\%)\end{array}$ & Kappa \\
\hline \multicolumn{13}{|l|}{1984 classified data } \\
\hline Mangroves & 123 & 0 & 0 & 0 & 0 & 0 & 0 & 0 & 100 & 100 & 86.58 & 0.85 \\
\hline Savannah & 0 & 102 & 110 & 0 & 0 & 0 & 0 & 0 & 73.91 & 48.11 & & \\
\hline Forests & 0 & 18 & 196 & 0 & 0 & 0 & 0 & 0 & 64.05 & 88.29 & & \\
\hline Salt marshes & 0 & 0 & 0 & 152 & 0 & 0 & 0 & 0 & 86.36 & 100 & & \\
\hline Sabkha & 0 & 0 & 0 & 24 & 128 & 0 & 0 & 0 & 100 & 84.21 & & \\
\hline Water bodies & 0 & 0 & 0 & 0 & 0 & 163 & 0 & 0 & 100 & 100 & & \\
\hline Bare lands & 0 & 18 & 0 & 0 & 0 & 0 & 107 & 0 & 100 & 85.60 & & \\
\hline Croplands & 0 & 0 & 0 & 0 & 0 & 0 & 0 & 177 & 95.68 & 100 & & \\
\hline
\end{tabular}




\begin{tabular}{|c|c|c|c|c|c|c|c|c|c|c|c|c|}
\hline \multirow{2}{*}{$\begin{array}{l}\text { Land use/cover } \\
\text { types }\end{array}$} & \multicolumn{8}{|c|}{ Ground truth (pixels) } & \multicolumn{4}{|c|}{ Accuracy assessment } \\
\hline & Mangroves & Savannah & Forests & $\begin{array}{l}\text { Salt } \\
\text { marshes }\end{array}$ & Sabkha & $\begin{array}{l}\text { Water } \\
\text { bodies }\end{array}$ & $\begin{array}{l}\text { Bare } \\
\text { lands }\end{array}$ & Croplands & $\begin{array}{l}\text { Prod } \\
\text { Acc. } \\
(\%)\end{array}$ & $\begin{array}{l}\text { Users } \\
\text { Acc. } \\
(\%)\end{array}$ & $\begin{array}{l}\text { Ov } \\
\text { Acc } \\
(\%)\end{array}$ & Kappa \\
\hline \multicolumn{13}{|l|}{1994 classified data } \\
\hline Mangroves & 124 & 0 & 0 & 0 & 0 & 0 & 0 & 0 & 100 & 100 & 88.13 & 0.86 \\
\hline Savannah & 0 & 32 & 84 & 0 & 0 & 0 & 0 & 40 & 30.48 & 20.51 & & \\
\hline Forests & 0 & 0 & 265 & 0 & 0 & 0 & 0 & 0 & 75.50 & 97.79 & & \\
\hline Salt marshes & 0 & 0 & 0 & 133 & 0 & 0 & 0 & 0 & 100 & 100 & & \\
\hline Sabkha & 0 & 0 & 0 & 0 & 217 & 0 & 0 & 0 & 100 & 100 & & \\
\hline Water bodies & 0 & 0 & 0 & 0 & 0 & 372 & 0 & 0 & 100 & 100 & & \\
\hline Bare lands & 0 & 1 & 0 & 0 & 0 & 0 & 132 & 2 & 100 & 96.35 & & \\
\hline Croplands & 0 & 66 & 0 & 0 & 0 & 0 & 0 & 218 & 83.85 & 76.76 & & \\
\hline \multicolumn{13}{|l|}{2007 classified data } \\
\hline Mangroves & 105 & 0 & 0 & 0 & 0 & 0 & 0 & 0 & 100 & 100 & 97.22 & 0.97 \\
\hline Savannah & 0 & 122 & 0 & 0 & 0 & 0 & 0 & 1 & 100 & 99.19 & & \\
\hline Forests & 0 & 0 & 337 & 0 & 0 & 0 & 12 & 0 & 94.40 & 96.56 & & \\
\hline Salt marshes & 0 & 0 & 0 & 119 & 0 & 0 & 0 & 0 & 100 & 100 & & \\
\hline Sabkha & 0 & 0 & 0 & 0 & 150 & 0 & 0 & 0 & 95.54 & 100 & & \\
\hline Water bodies & 0 & 0 & 0 & 0 & 0 & 271 & 0 & 0 & 100 & 100 & & \\
\hline Bare lands & 0 & 0 & 17 & 0 & 2 & 0 & 130 & 0 & 91.55 & 87.25 & & \\
\hline Croplands & 0 & 0 & 3 & 0 & 5 & 0 & 0 & 165 & 99.40 & 95.40 & & \\
\hline \multicolumn{13}{|l|}{2017 classified data } \\
\hline Mangroves & 136 & 0 & 0 & 0 & 0 & 0 & 0 & 0 & 100 & 100 & 99.68 & 0.99 \\
\hline Savannah & 0 & 158 & 0 & 0 & 0 & 0 & 0 & 0 & 100 & 100 & & \\
\hline Forests & 0 & 0 & 174 & 0 & 0 & 0 & 0 & 0 & 100 & 100 & & \\
\hline Salt marshes & 0 & 0 & 0 & 179 & 0 & 0 & 0 & 0 & 100 & 100 & & \\
\hline Sabkha & 0 & 0 & 0 & 0 & 139 & 0 & 0 & 0 & 100 & 100 & & \\
\hline Water bodies & 0 & 0 & 0 & 0 & 0 & 173 & 0 & 0 & 100 & 100 & & \\
\hline Bare lands & 0 & 0 & 0 & 0 & 0 & 0 & 136 & 3 & 99.27 & 97.84 & & \\
\hline Croplands & 0 & 0 & 0 & 0 & 0 & 0 & 1 & 174 & 98.31 & 99.43 & & \\
\hline
\end{tabular}

\section{Appendix 2 Soil salinity predictors from the regres- sion analysis}

\begin{tabular}{llllrr}
\hline $\begin{array}{l}R^{2} \text { of } \\
\text { models }\end{array}$ & $\begin{array}{l}\text { Explana- } \\
\text { tory vari- } \\
\text { ables }\end{array}$ & Coef & Std. Err & 95\% Conf. interval \\
\hline$R^{2}=0.73$ & $\begin{array}{l}\text { Intercept } \\
\text { Distance } \\
\text { to river } \\
\text { (m) }\end{array}$ & -0.001 & $0.000^{* * *}$ & -0.001 & 0.000 \\
& & & & \\
& Elevation & -0.209 & $0.040^{* * *}$ & -0.287 & -0.131 \\
& (m) & & & & \\
& NDVI & -6.582 & $0.023^{* * *}$ & -14.499 & 1.335 \\
& TWI & 0.000 & 0.000 & 0.000 & 0.000 \\
\hline
\end{tabular}

\begin{tabular}{|c|c|c|c|c|c|}
\hline \multirow{2}{*}{$\begin{array}{l}R^{2} \text { of } \\
\text { models } \\
R^{2}=0.57\end{array}$} & \multirow{2}{*}{$\begin{array}{l}\text { Explana- } \\
\text { tory vari- } \\
\text { ables } \\
\text { Intercept }\end{array}$} & \multirow{2}{*}{$\begin{aligned} \text { Coef } \\
5.646\end{aligned}$} & \multirow{2}{*}{$\begin{array}{l}\text { Std. Err } \\
3.757^{*} * *\end{array}$} & $95 \%$ Conf & interval \\
\hline & & & & -1.748 & 13.042 \\
\hline & $\begin{array}{l}\text { Distance } \\
\text { to river } \\
\text { (m) }\end{array}$ & -0.000 & $0.000 * * *$ & -0.000 & -0.000 \\
\hline & $\begin{array}{l}\text { Elevation } \\
\text { (m) }\end{array}$ & -0.186 & 0.037 *** & -0.262 & -0.113 \\
\hline & SI & 0.000 & 0.000 & -0.000 & 0.000 \\
\hline & TWI & 0.000 & 0.000 & -0.000 & 0.000 \\
\hline \multirow[t]{5}{*}{$R^{2}=0.55$} & Intercept & 7.267 & $2.616^{* * *}$ & 2.117 & 12.416 \\
\hline & $\begin{array}{l}\text { Distance } \\
\text { to river } \\
\text { (m) }\end{array}$ & -0.000 & $0.000^{* * *}$ & -0.000 & -0.000 \\
\hline & $\begin{array}{l}\text { Elevation } \\
\text { (m) }\end{array}$ & -0.187 & $0.037 * * *$ & -0.261 & -0.112 \\
\hline & SAVI & 6.622 & 0.000 & -0.000 & 0.000 \\
\hline & TWI & 0.000 & 0.000 & -0.000 & 0.000 \\
\hline
\end{tabular}


Acknowledgements This study was performed within the West African Science Service Centre on Climate Change and Adaptive Land Use (WASCAL) program, funded by the German Federal Ministry of Education and Research (BMBF). We are grateful to the farming population of Djilor district and to all our field assistants for their collaborations. We would like to also acknowledge the support of the Agriculture and Rural Development Office of Djilor, Union International for conservation of Nature (UICN) for their support in providing necessary information and helping in the data collection.

Author contribution Sophie Thiam and Grace B. Villamor wrote the main manuscript text and also did the conceptualization. Sophie Thiam, Laurice C. Faye and Jean Henri Bienvenue Sène collected the data (soil and satellite images). Sophie Thiam and Badabate Diwediga described the land use and their classification. Nicholas Kyei-Baffour and Grace B. Villamor supervised the work. All the authors reviewed and edited the manuscript.

Funding Open Access funding enabled and organized by Projekt DEAL.

\section{Declarations}

Conflict of interest The authors declare that they have no conflict of interest.

Open Access This article is licensed under a Creative Commons Attribution 4.0 International License, which permits use, sharing, adaptation, distribution and reproduction in any medium or format, as long as you give appropriate credit to the original author(s) and the source, provide a link to the Creative Commons licence, and indicate if changes were made. The images or other third party material in this article are included in the article's Creative Commons licence, unless indicated otherwise in a credit line to the material. If material is not included in the article's Creative Commons licence and your intended use is not permitted by statutory regulation or exceeds the permitted use, you will need to obtain permission directly from the copyright holder. To view a copy of this licence, visit http://creativecommons.org/licenses/by/4.0/.

\section{References}

Abd El-Kawy, O. R., Rød, J. K., Ismail, H. A., \& Suliman, A. S. (2011). Land use and land cover change detection in the western Nile delta of Egypt using remote sensing data. Applied Geography, 31(2), 483-494. https://doi.org/10.1016/j.apgeog. 2010.10.012

Abdi, A. M. (2020). Land cover and land use classification performance of machine learning algorithms in a boreal landscape using Sentinel-2 data. GIScience and Remote Sensing, 57(1), 1-20. https://doi.org/10.1080/15481603.2019.1650447
Abdul Qados, A. M. S. (2011). Effect of salt stress on plant growth and metabolism of bean plant Vicia faba (L.). Journal of the Saudi Society of Agricultural Sciences, 10(1), 7-15. https:// doi.org/10.1016/j.jssas.2010.06.002

Aldwaik, S. Z., \& Pontius, R. G., Jr. (2012). Landscape and Urban Planning Intensity analysis to unify measurements of size and stationarity of land changes by interval, category, and transition. Landscape and Urban Planning, 106(1), 103-114. https://doi.org/10.1016/j.landurbplan.2012.02.010

Allbed, A., \& Kumar, L. (2013). Soil salinity mapping and monitoring in arid and semi-arid regions using remote sensing technology: A review. Advance in Remote Sensing, 2(December), 373-385. https://doi.org/10.4236/ars.2013.24040

Allbed, A., Kumar, L., \& Sinha, P. (2014). Mapping and modelling spatial variation in soil salinity in the Al Hassa Oasis based on remote sensing indicators and regression techniques. Remote Sensing, 6(2), 1137-1157. https://doi.org/10.3390/rs6021137

Allbed, A., Kumar, L., \& Sinha, P. (2017). Soil salinity and vegetation cover change detection from multi-temporal remotely sensed imagery in Al Hassa Oasis in Saudi Arabia. Geocarto International, 6049. https://doi.org/10.1080/10106049.2017. 1303090

Azabdaftari, A., \& Sunar, F. (2016). Soil Salinity Mapping Using Multitemporal Landsat Data. Remote Sensing and Spatial Information Sciences, 7, 3-9. https://doi.org/10. 5194/isprsarchives-XLI-B7-3-2016

Barry, N. Y., Traore, V. B., Ndiaye, M. L., Isimemen, O., Celestin, H., \& Sambou, B. (2017). Assessment of climate trends and land cover / use dynamics within the Somone River Basin, Senegal. Scientific Research Publishing, 513-538. https://doi. org/10.4236/ajcc.2017.63026

Dahal, H., \& Routray, J. K. (2011). Identifying associations between soil and production variables using linear multiple regression models. The Journal of Agriculture and Environment, 12, 27-37. https://doi.org/10.3126/aej.v12i0.7560

Daliakopoulos, I. N., Tsanis, I. K., Koutroulis, A., Kourgialas, N. N., Varouchakis, A. E., Karatzas, G. P., \& Ritsema, C. J. (2016). The threat of soil salinity: A European scale review. Science of the Total Environment, 573, 727-739. https://doi. org/10.1016/j.scitotenv.2016.08.177

Dehni, A., \& Lounis, M. (2012). Remote sensing techniques for salt affected soil mapping: Application to the Oran Region of Algeria. Procedia Engineering, 33, 188-198. https://doi.org/10. 1016/j.proeng.2012.01.1193

Descroix, L., Sané, Y., Thior, M., Manga, S. P., Ba, B. D., Mingou, J., \& Vandervaere, J. P. (2020). Inverse estuaries in West Africa: Evidence of the rainfall recovery? Water (Switzerland), 12(3), 647. https://doi.org/10.3390/w12030647

Diwediga, B., Agodzo, S., Wala, K., \& Le, Q. B. (2017). Assessment of multifunctional landscapes dynamics in the mountainous basin of the Mo River (Togo, West Africa). Journal of Geographical Sciences, 27(5), 579-605. https://doi.org/10. 1007/s11442-017-1394-4

Emad, F. A., \& Emad, A. (2017). Detection of soil salinity for bare and cultivated lands using landsat ETM+ imagery data: A case study from El-Beheira Governorate, Egypt. Alexandria Science Exchange Journal: An International Quarterly Journal of Science Agricultural Environments, 38, 642-653. https://doi.org/10.21608/asejaiqjsae.2017.4055 
Fall, A. C. A. L., Montoroi, J. P., \& Stahr, K. (2014). Coastal acid sulfate soils in the Saloum River basin, Senegal. Soil Research, 52(7), 671-684. https://doi.org/10.1071/SR14033

FAO/CSE. (2003). L'evaluation de la degradation des terres au Sénégal. Projet Fao Land Degradation Assessment (LADA). p. 62.

Faye, L. C., Sambou, H., Kyereh, B., \& Sambou, B. (2016). Land use and land cover change in a community-managed forest in South-Eastern Senegal under a formal forest management regime. American Journal of Environmental Protection, 5(1), 1. https://doi.org/10.11648/j.ajep.20160501.11

Faye, S., Maloszewski, P., Stichler, W., Trimborn, P., Faye, S. C., \& Gaye, C. B. (2005). Groundwater salinization in the Saloum (Senegal) delta aquifer: Minor elements and isotopic indicators. Science of the Total Environment, 343(1-3), 243-259. https://doi.org/10.1016/j.scitotenv.2004.10.001

Faye, W., Fall, A. N., Orange, D., Do, F., Roupsard, O., \& Kane, A. (2020). Climatic variability in the Sine-Saloum basin and its impacts on water resources: case of the Sob and Diohine watersheds in the region of Niakhar. Proceedings of the International Association of Hydrological Sciences, 383, 391-399. https://doi.org/10.5194/piahs-383-391-2020

Ivushkin, K., Bartholomeus, H., Bregt, A. K., Pulatov, A., \& Kempen, B. (2019). Remote Sensing of Environment Global mapping of soil salinity change. Remote Sensing of Environment, 231(March), 111260. https://doi.org/10. 1016/j.rse.2019.111260

Jabbar, M. T., \& Zhou, J. (2012). Assessment of soil salinity risk on the agricultural area in Basrah Province, Iraq: Using remote sensing and GIS techniques. Journal of Earth Science, 23(6), 881-891. https://doi.org/10.1007/ s12583-012-0299-5

Kairis, O., Kosmas, C., Karavitis, C., Ritsema, C., Salvati, L., Acikalin, S., et al. (2013). Evaluation and selection of indicators for land degradation and desertification monitoring: types of degradation, causes, and implications for management, Springer Science+Business Media New York 2013. https:// doi.org/10.1007/s00267-013-0109-6

Legros, J. P. (2009). La salinisation des terres dans le monde. 257269. http://Academie.Biu-Montpellier.Fr/

Lhissou, R., \& Chokmani, K. (2014). Mapping soil salinity in irrigated land using optical remote sensing dat. Eurasian Journal of Science, 3, 82-88.

Manandhar, R., \& Odeh, I. (2014). Interrelationships of land use/ cover change and topography with soil acidity and salinity as indicators of land degradation. Land, 3(1), 282-299. https:// doi.org/10.3390/land3010282

Masoud, A. A., \& Koike, K. (2006). Arid land salinization detected by remotely-sensed land cover changes: A case study in the Siwa region, NW Egypt. Journal of Arid Environments, 66(1), 151-167. https://doi.org/10.1016/j.jaridenv.2005.10.011

Metternicht, G. I., \& Zinck, J. A. (2003). Remote sensing of soil salinity: Potentials and constraints. Remote Sensing of Environment, 85(1), 1-20. https://doi.org/10.1016/S00344257(02)00188-8

Morshed, M. M., Islam, M. T., \& Jamil, R. (2016). Soil salinity detection from satellite image analysis: an integrated approach of salinity indices and field data. Environmental Monitoring and Assessment, 188(2), 1-10. https://doi.org/10.1007/ s10661-015-5045-X
Narmada, K., Gobinath, K., \& Bhaskaran, G. (2015). Monitoring and evaluation of soil salinity in terms of spectral response using geoinformatics in Cuddalore environs. International Journal of Geomatics and Geosciences, 5(4), 536-543.

Parton, W., Tappan, G., Ojima, D., \& Tschakert, P. (2004). Ecological impact of historical and future land-use patterns in Senegal. Journal of Arid Environments, 59(3), 605-623. https:// doi.org/10.1016/j.jaridenv.2004.03.024

PLD. (2009). Plan de Developpement Local Programme National de Développement Local.

Poenaru, V., Badea, A., Cimpeanu, S. M., \& Irimescu, A. (2015). Multi-temporal multi-spectral and radar remote sensing for agricultural monitoring in the Braila Plain. Agriculture and Agricultural Science Procedia, 6, 506-516. https://doi.org/10. 1016/j.aaspro.2015.08.134

Sadio, S., \& van Mensvoort, M. E. F. (1993). Saline acid sulfate soils in Senegal. Selected Papers of the Ho Chi Minh City Symposium on Acid Sulphate Soils, (Figure I), 89-95.

Sakadevan, K., \& Nguyen, M. (2010). Extent, impact, and response to soil and water salinity in arid and semiarid regions. Advances in Agronomy, 109, 55-74. Elsevier Ltd. https://doi. org/10.1016/B978-0-12-385040-9.00002-5

Saleh, A. M. (2017). Evaluation of different soil salinity mapping using remote sensing indicators and regression techniques, Basrah, Iras. Journal of American Science, 13(10), 85-19. https://doi.org/10.7537/marsjas131017.10.Keywords

Sambou, A. (2016). Vegetation change, tree diversity and food security in the Sahel : A case from the salinity-affected Fatick province in Senegal $\mathrm{PhD}$ thesis. https://www.Researchgate.Net/ Publication/304539300 Vegetation, (August). https://doi.org/ 10.13140/RG.2.1.1315.4805

Sambou, A., Theilade, I., Fensholt, R., \& Ræbild, A. (2016). Decline of woody vegetation in a saline landscape in the Groundnut Basin, Senegal. Regional Environmental Change, 16(6), 1765-1777. https://doi.org/10.1007/s10113016-0929-z

Sambou, H., Sambou, B., Mbengue, R., Sadio, M., \& Sambou, P. C. (2015). Dynamics of land use around the micro-dam anti-salt in the sub-watershed of Agnack lower Casamance (Senegal). American Journal of Remote Sensing, 3(2), 29-36. https://doi.org/10.11648/j.ajrs.20150302.12

Sylla, M. (1994). Soil salinity and acidity: spatial variability and effects on rice production in West Africa's mangrove zone. Mabeye Sylla Ph.D. Thesis; Wageningen. ISBN 90-5485286-0. https://edepot.wur.nl/202352

Taghadosi, M. M., \& Hasanlou, M. (2017). Trend analysis of soil salinity in different land cover types using Landsat time series data (case study Bakhtegan Salt Lake). International Archives of the Photogrammetry, Remote Sensing and Spatial Information Sciences - ISPRS Archives, 42(4W4), 7-10. https://doi. org/10.5194/isprs-archives-XLII-4-W4-251-2017

Thiam, S., Villamor, G. B., Kyei-ba, N., \& Matty, F. (2019). Land Use Policy Soil salinity assessment and coping strategies in the coastal agricultural landscape in Djilor district. Senegal. Land Use Policy, 88, 104191. https://doi.org/10.1016/j. landusepol.2019.104191

Tripathi, N. K., Rai, B. K., \& Dwivedi, P. (1997). Spatial modelling of soil alkalinity in GIS environment using IRS data. In Proceedings of the 18th Asian Conference in Remote Sensing, ACRS Kuala Lumpur, Malaysia, 20-25 October 1997. https:// 
www.geospatialworld.net/article/spatial-modelling-of-soilalkalinity-in-gis-environment-using-irs-data/

Villamor, G. B., Pontius, R. G., \& van Noordwijk, M. (2013). Agroforest's growing role in reducing carbon losses from Jambi (Sumatra), Indonesia. Regional Environmental Change, 14(2), 825-834. https://doi.org/10.1007/ s10113-013-0525-4

Wiegand, C., Anderson, G., Lingle, S., \& Escobar, D. (1996). Soil salinity effects on crop growth and yield - Illustration of an analysis and mapping methodology for sugarcane. Journal of Plant Physiology, 148(3-4), 418-424. https://doi.org/10.1016/S01761617(96)80274-4

Wilson, N. R., Norman, L. M., Villarreal, M., Gass, L., Tiller, R., Salywon, A., \& Tiller, R. (2016). Comparison of remote sensing indices for monitoring of desert cienegas ABSTRACT. Arid Land Research and Management, 30(4), 460-478. https://doi.org/10.1080/15324982.2016. 1170076
Wu, J., Vincent, B., Yang, J., Bouarfa, S., \& Vidal, A. (2008). Remote sensing monitoring of changes in soil salinity: A case study in Inner Mongolia, China. Sensors, 8(11), 7035-7049. https://doi.org/10.3390/s8117035

Yossif, M. H. (2017). Change Detection of Land Cover and Salt Affected Soils at Siwa Oasis. Egypt.

Zhang, T. T., Zeng, S. L., Gao, Y., Ouyang, Z. T., Li, B., Fang, C. M., \& Zhao, B. (2011). Using hyperspectral vegetation indices as a proxy to monitor soil salinity. Ecological Indicators, 11(6), 1552-1562. https://doi.org/10.1016/j. ecolind.2011.03.025

Publisher's Note Springer Nature remains neutral with regard to jurisdictional claims in published maps and institutional affiliations. 